\title{
Dystopia of Transhumanism in the Context of General Eschatology
}

\author{
Gleb D. Leontyev, Vladimir I. Kurashov
}

\begin{abstract}
They analyzed the socio-anthropological essence of nano-, bio-, info-, cogno- (NBIC) convergence process and the concept of transhumanism. The general contours of the "ideal", transhuman, convergent-technological future are examined on the basis of the concept of "general eschatology", which made it possible to justify the presence of humanitarian threats and risks, their prolongation from the present to the future and dystopic deepening in the convergent process of "trans-transition". Dystopic trends with the opportunity to be implemented in practice are the following ones: loss of individual uniqueness; fading of the moral principle; technological inequality and socio-stratification polarization; social manageability based on interference in human nature; consequences of total control over consciousness in the field of rights and freedoms. The eschatological approach reveals the essential difference between the concepts of "humanism" and "transhumanism" in terms of human values: the preservation of the human in a person or its overcoming through NBIC- "reformatting" of a person. The dominance of the managerial approach in the organization of science affects the process of scientific activity self-organization, transforms the natural convergence process of sciences and technologies, giving rise to moral, financial, and corporate deviations. Technological opportunities produced by the modern era testify to the multivariance of prognostic vision forms of the future, the relevance of the philosophical, methodological, humanitarian examination of "breakthrough technologies" to preserve humanity.
\end{abstract}

Keywords: dystopia, humanism, transhumanism, NBIC convergence, general eschatology, technology, social risks.

\section{INTRODUCTION}

The current intensity of technological breakthroughs in science and technology gives rise to new, post-non-classical forms of prognostic vision. In accordance with the singularity concept by V. Vinge, the exhibitor of scientific and technological development strives to become a straight, vertical line [1]. Thus, according to the French philosopher J. Ellul, the habitat of a person is no longer nature, but technique [2], "which, on the one hand, frees a person, and on the other, deforms his humanistic principles" [3, p. 80], giving rise to the "phenomenon of social and psychological exclusion" in the ICT era [4]. As a result, the worldview is represented by both techno-pessimism or technological alarmism (French "alarmiste" - "anxiety"), and technological eudaimonism (Greek "eudaimonia" - "bliss"), i.e. optimistic hopes.

Revised Manuscript Received on November 08, 2019.

* Correspondence Author

Gleb D. Leontyev, Kazan Federal University, Institute of Philosophy, Social Sciences and Mass Communication, Russia; Kazan National Research Technological University, Russia

Vladimir I. Kurashov, Kazan National Research Technological University, Russia
The term "NBIC convergence" ("Converging Technologies for Human Performance Improvement" report, World Technology Evaluation Center (WTEC), 2002) was coined by Michael Rocco and William Bainbridge. The essence of the process, designated by the acronym NBIC, is the synergistic effect of the following scientific and technical field interaction: nanotechnology; biotechnology and biomedicine; information and communication technologies; cognitive sciences. The result of the progress of technologies and their convergence is the establishment of a radically new technological structure. Based on the theory of economic cycles by N. Kondratiev, which are conditioned by the change in the dominant technologies and related social institutions, prof. G. Malinetsky [5] believes that the fifth cycle, which marked the development of electronics, robotics, computing, laser and telecommunications is currently ending. It is predicted that the sixth technological order, based on the convergence of innovative technologies, will last until the 2060-ies. However, already since 2045 (R. Kurzweil, Google technical director) or the 2050-ies (Masayoshi Son, Softbank general director), they predict the onset of "technological singularity" [6], i.e. hypothetical explosive acceleration of scientific and technological development, which is currently impossible to analyze. If the hypothesis of prof. G. Malinetsky is faithful and society is at the final stage of the next cycle, i.e. in a situation of extreme instability, it is hypersensitive to the slightest fluctuations, which can have not only technological, but also sociocultural, political nature. The worldview reflection of this technological process is the concept of transhumanism.

The term "transhumanism" was proposed by the English biologist, the first director general of UNESCO, J. Huxley, in 1957 for the presentation of a synthetic theory of evolution. In accordance with the official interpretation of the Russian transhumanist movement (transhumanism-russia.ru), it is "a rational worldview, based on understanding the achievements and prospects of science, that recognizes the possibility and desirability of fundamental changes in the human condition using advanced technologies." In the logic of transhumanists, the rends are being developed for a revolutionary upgrade of human biology ("posthuman") as the conditions for the preservation of anthropogenic civilization instead of transformation of civilization itself ("counter-civilization", E. Toffler) as the condition for the preservation of human traits in a man.

\section{METHODS}

The methodological basis of the study is the concepts that substantiate the qualitative specificity and social risks of a post-industrial society [7]. First of all, this is the statement of the convergence process of 
technology, communication and culture, "the interdependence between biological and microelectronic revolutions" [8, p. 78], noted by M. Castels and F. Fukuyama's warning about the alleged absence of a "universal human" in the "posthuman" world [9]. The threats generated by modern, technogenic civilization actualize the concept of "general eschatology" [10, 11, 12], introduced almost a quarter of century ago by one of the authors of this study, Professor V.I. Kurashov. In the framework of this concept, during understanding the finiteness of human existence fate, the emphasis is on the complexity, interconnection of religious, philosophical, scientific points of view, on the development of the worldview and methodological foundations of human self-preservation.

\section{RESULTS AND DISCUSSION}

The convergence process of exponentially expanding areas of technology is a clear trend of our time, difficult to predict for its socio-political, economic, and scientific and technological consequences. Substantially, the NBIC initiative has two aspects: 1) integration and transformation of economy and technology; 2) "improving human performance", "human enhancement" [13, p. 69]. Techno-determinism of the second trend involves applied projects based on fundamental cognitive research for genetically modified, nano-cyborgized, virtual-digital person development. Thus, high technologies become the mode of incarnation of a person, marking the coming of a new creature into the world, defined in terms of techno-man, trans-man, post-man, e-Homo. Trying to emphasize the new content of fundamental values, prof. D. I. Dubrovsky introduces the term "neo-man." The birth of new existential meanings in a new era is quite acceptable, but what kind of being will be their bearer if the boundaries of the human are overcome in all available coordinate systems - natural science, moral, aesthetic? The transhumanist attitude is justified by the bio-social imperfection of modern man, who is burdened by internal conflicts and gives rise to global crises with his external activity. Therefore, in order to avoid an anthropogenic catastrophe, one should "either change the biological nature of a person through reconstructions in his genome .., or go along the path of embodiment of reason and social personality in a non-biological self-organizing system" [14]. That is, together with the crisis generated by human activity, the very subject of this activity is overcome - the person. Carrying out such a scenario, future generations will have neither a body nor a soul. "This is a variant of the absolute inevitability of the outcome (end) of all life in the Universe, stemming from modern "optimistic" science" [10].

The convergence of scientific and technological innovations is the process of interdisciplinary research that is in line with the natural course of scientific development, demanded in the framework of post-non-classical rationality. Convergence "occurs de facto when a specific product is created ... Metaphysical convergence ... has nothing to do with scientific reality" according to A. Greenbaum, the coordinator of the European Observatory of Nanotechnology [15]. However, in a public, especially Russian space, "technology convergence" acquires the status of a cognitive fashion trend, a media agenda, and even politics and ideology. Such a situation is fraught both for science and for society with deviations of a moral, corporate, financial and other nature. Firstly, the "convergent" boom ended ten years ago in the leading Western countries and is defined by scientists as "political rhetoric". Secondly, if, on the basis of breakthrough technologies, interventions in the human psyche and corporeality ever become massively applied, they will inevitably violate the "body" and "collective mind" of society, since a person himself is the part of his knowledge object - global, historical, socio-natural system. This means that a person can also explore it only from the inside, without being able to go beyond it. Since such systems "in all its temporal integrity" have not been implemented yet, in the cognitive aspect, the permanent situation of human existence is "incompleteness of knowledge about the past and incompleteness of the future" $[11,21]$. It is the fact of such cognitive "doom" of a person that ignores socio-technological determinism, which produces an increase in anthropogenic pressure on bio- and sociosphere.

Recognizing the social relevance of scientific and technological achievements to improve the quality of life, the NBIC European Commission defined its goal as "Converging Technologies for the European Knowledge Society" [16, p. 4]. "For society" means the instrumental complementarity of technology, the rejection of "reconstruction of man, posthuman." The French philosopher Bensaude-Vincent B. relates the promises of NBIC reports (2002-2003) "to a hybrid genre in between propaganda, ideology and science", whose goal is to attract investors and sponsors. Bensaude-Vincent sees a positive consequence of this concept public presentation in the development of social discourse, which obliges social monitoring of innovation, which means that "scientists no longer work in their ivory tower and that the public has to be engaged in science" $[16,20]$. Thus, the French philosopher concludes, "technoscience", initiating the convergent process, turns the world into a laboratory where the awareness and social responsibility of each actor is the means of individual and collective survival.

Technology for society and a man or a man and society for technology: this is the essence of the difference in the approaches which determine socio-technological prospects. Humanism or transhumanism: preservation of a person's self-consciousness on the basis of distinguishing oneself from the environment or qualitatively overcoming the boundaries of subjectivity and, thus, its loss and trans-transition. On the one hand, the classical humanism of the New Age combines the theory of transhumanism with its rationalist essence, scientific basis, the absolute priority of reason and the idea of unlimited progress, on the other hand, the deepest difference lies in the relation to a person: is it the highest value or an experimental object. The idea of a society of rational people created through "programmed learning" using techniques to modify behavior was laid down by the classic of behaviorism B. Skinner. His rational and happy individual from the novel "Walden Two" functions from the point of view of expediency for society, because an "independent person", according to the American psychologist, is a concept created by our "ignorance," which means it loses its meaning during cognitive and other technology development. Approaching such an "ideal" individual is achievable "on the other side of good and evil", freedom and dignity, where life activity is not 
burdened with moral qualities and free will. In our opinion, modern transhumanism has similar hopes for the managerial effectiveness of "excessive" elements amputation in a person.

Forecasts are always probabilistic, however, at present, scientific and technical forecasting has a greater degree of reliability than social forecasting, since technologies affect all spheres of society increasingly. But in the process of projecting techno-forecasts to a society that is at the same time the creator, customer and consumer of each specific idea, a peculiar refraction effect occurs. Thus, the final "product", having passed through the prism of the social, can have, firstly, a politically engaged character, catalyzing certain processes to radical actions. Secondly, there is an unverifiable nature, due to the action of "natural social" and "anthropogenic spiritual" factors. From the eschatological point of view, the millennial existence of human culture and civilization is not a scientific basis for confidence in its absolute stability. The opponents explain the negative attitude of a part of the philosophical community to the idea of techno-bio-evolution of man by the following factors: 1) traditions (the idea contradicts spiritual and moral values); 2) aesthetics (loss of human appearance); 3) the end (posthumanity is associated with inhumanity, with a dead end) $[17,18,19]$. Similarly, we can conclude that the desire to overcome dominates in the world-view of the adherents of trans-transition idea: 1) moral boundaries and not commercialized spirituality dominates; 2) the canons of human bodily beauty as a random branch of evolution; 3) all that exists in search of a new inhuman dimension. Technological innovations that make life easier, advance human society from primates to an unknown future, develop according to the laws of the scientific genre. The same scientific logic, taking into account the specifics of social laws and social self-organization, is also in demand from the humanitarian community. It is eschatology that "brakes" technology at sharp turns. Acceleration and inhibition, constancy and development, traditions and innovations - a socially balanced, innovative future is born in this classic, eternal dialectic of opposites.

\section{IV.SUMMARY}

The extension of humanitarian risks from the present to the future indicates the dystopian nature of the "trans-transition." The following social threats were identified from the standpoint of general eschatology: loss of individual uniqueness; redundancy of the world of "moral freedom"; ICT inequality; "Posthumanity" of the ruling subject; controllability of neurosocium; the consequences of total control over consciousness in the field of natural and political rights, freedoms, privacy and sovereignty. Consequently, the essence of the same root concepts of "humanism" and "transhumanism" is fundamentally different with respect to the status of a person: either he is the goal of social development, or an instrument of social engineering.

\section{CONCLUSIONS}

The recognition of anthropogenic crisis evidence in post-industrial society raises the question of the ways for its overcoming. The worldview foundations of anti-crisis practice are opposite in the contemporary philosophical discourse: on the one hand, it is an optimistic belief in unlimited optimization of "neo-man" capabilities, on the other hand, pessimistic fears of technology impact on the ecology of the "classic man" spiritual and mental environment

\section{ACKNOWLEDGEMENTS}

The work is performed according to the Russian Government Program of Competitive Growth of Kazan Federal University.

\section{REFERENCES}

1. Vinge Vernor. The Coming Technological Singularity. VISION-21 Symposium, NASA Lewis Research Center and the Ohio Aerospace Institute, March 30-31, $1993 . \quad$ - URL: https://www.accelerating.org/articles/comingtechsingularity.html

2. Ellul J. The Technological Order / J. Ellul // The Technological Order Ed. C.F. Stover. Detroit: Wayne State Univ. Press, 1963, 10-37 pp.

3. Leontiev G.D. Anti-utopianism of postmodernism or utopian post-modern? / G.D. Leontiev // News of Ural Federal University. Series No. 3. Social sciences. - 2017. V.12. - № 2 (164). - pp. 78-86.

4. Leontyev, G. D. Dialectics of freedom and alienation in the space of the internet / G. D. Leontyev, A. M. Safina, L. F. Gaynullina, L.S Leontieva et al. // Revista ESPACIOS (ISSN 07981015 -Venezuela-Scopus). Vol. 39 (N²7) Year 2018. Page 8. - URL: http://www.revistaespacios.com/a18v39n27/18392708.html

5. Malinetsky G. Designing the future and modernization of Russia / G Malinetsky // Friendship of Peoples. - 2010. - No. 9. - pp. 167-187.

6. Kurzweil Ray. How to Create a Mind: The Secret of Human Thought Revealed. Penguin Books, 2013. - 352 p.

7. Masuda, Y. The Information Society as Postindustrial Society / Y Masuda. - Wash.: World Future Soc., 1983. - 419 p.

8. Castells M. Information Age: Economics, Society and Culture / M Castells; translation from English under scientific ed. by O.I. Shkaratan. - M.: SU-HSE, 2000. - 608 p.

9. Fukuyama Francis. Our Posthuman Future: Consequences of the Biotechnology Revolution.- New York: Farrar, Straus, and Giroux, 2002. - 256 pp.

10. Kurashov V.I. Ecology and eschatology (Fates of human existence from a religious and scientific point of view) / V.I. Kurashov // Issues of Philosophy No. 3 - 1995. - pp. 29-36.

11. Kurashov V.I. The origins of pragmatic anthropology. - M.: KDU, 2007. - 304 p.

12. Kurashov V.I. Ecology and Eschatology // Russian Studies in Philosophy, Winter 1998-99.-Vol. 37, № 3. - pp. 8-19.

13. V. Arshinov "Network Path" of modern nano-techno-scientific practice / V.I. Arshinov // Scientific and journalistic journal NBICS-Nauka. Technology. - 2017 (1). - No. 1. - pp. 66-76.

14. Dubrovsky D.I. The biological roots of the anthropological crisis What's next? / D.I. Dubrovsky // Man. - 2012. - No. 6. - pp. 51-54.

15. Dobrynin S. Service people of Mikhail Kovalchuk // Radio Liberty. 01/26/2016. - URL: https://www.svoboda.org/a/27511650.html

16. Bensaude-Vincent B. Technoscience and Convergence: A Transmutation of Values? // Summerschool on Ethics of Converging Technologies. Dormotel Vogelsberg, Omrod/Alsfeld, Germany. 2008. pp.10.-

URL: https://halshs.archives-ouvertes.fr/file/index/docid/350804/filename/0 6BBV.pdf

17. Alekseeva I. Yu., Arshinov V.I., Chekletsov V.V. "Techno-humans" versus "posthumans": NBIKS-revolution and the future of man / I.Yu. Alekseeva, V.I. Arshinov, V.V. Chekletsov // The issues of philosophy. - 2013.- No. 3. - pp. 12-21.

18. Suleri, J., \& Cavagnaro, E. Promoting pro-environmental printing behavior: The role of ICT barriers and sustainable values. International Journal of Education and Development using ICT, (2016). 12(2).

19. Gamarra, M., Zurek, E., \& San-Juan, H. Addendum for: A Study of Image Analysis Algorithms for Segmentation, Feature Extraction and Classification of Cells. Journal of Information Systems Engineering \& Management, 3(1), (2018). 05 
20. Alkhateeb, M. Multiple Representations in 8th Grade Mathematics Textbook and the Extent to which Teachers Implement Them. International Electronic Journal of Mathematics Education, 14(1), (2019). 137-145. https://doi.org/10.12973/iejme/3982

21. Taubaye, Z., Rivers, W., Mussabekova, U., \& Alimbayeva, A. Peculiarities and problems of eponyms (on the material of Kazakhstani periodicals). Opción, 34(85-2), (2018). 221-236 